BNL- 63480

\title{
EVALUATING THE RISK OF AIR POLLUTION TO FORESTS IN CENTRAL AND EASTERN EUROPE
}

\author{
D. S. Ellsworth \\ Department of Applied Science \\ Biosystems and Process Sciences Division \\ Brookhaven National Laboratory \\ Upton, NY 11973 \\ and \\ J. Oleksyn \\ Polish Academy of Sciences \\ Institute of Dendrology \\ Parkowa 5 \\ PL-62-035 Kornik, Poland
}

September 1996

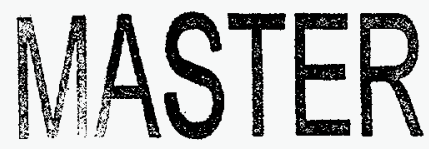

Published in:

"Science and Technology to Save and Better Utilize Central and Eastern Europe's Forests"

R. M. Gutkowski, Editor

NATO ASI Series E, Kluwer Academic Publishers, Dordrecht

This research was performed under the auspices of the U.S.

Department of Energy under Contract No. DE-AC02-76CH00016.

By acceptance of this article, the publisher and/or recipient acknowledges the U.S. Government's right to retain a nonexclusive, royalty-free license in and to any copyright covering this paper. 


\section{DISCLAMMER}

Portions of this document may be illegible in electronic image products. Images are produced from the best available original document. 
This report was prepared as an account of work sponsored by an agency of the United States Government. Neither the United States Government nor any agency thereof, nor any of their employees, makes any warranty, express or implied, or assumes any legal liability or responsibility for the accuracy, completeness, or usefulness of any information, apparatus, product, or process disclosed, or represents that its use would not infringe privately owned rights. Reference herein to any specific commercial product, process, or service by trade name, trademark, manufacturer, or otherwise does not necessarily constitute or imply its endorsement, recommendation, or favoring by the United States Government or any agency thereof. The views and opinions of authors expressed herein do not necessarily state or reflect those of the United States Government or any agency thereof.

\title{
EVALUATING THE RISK OF AIR POLLUTION TO FORESTS IN CENTRAL AND EASTERN EUROPE'
}

\author{
D.S. ELLSWORTH \\ Department of Applied Science \\ Brookhoven National Laboratory \\ Upton, N.Y. 11973 U.S.A. \\ ellswort@bnl.gov \\ J. OLEKSYN \\ Polish Academy of Sciences \\ Institute of Dendrology \\ Parkowa 5 \\ PL-62-035 Kórnik, Poland
}

\begin{abstract}
Foliar damage to trees by air pollution in Central and Eastem Europe has been a major scientific and political issue. Emissicns of toxic gases such as sulfur dioxide and nitrogen oxides can have wide-räigirg effects on local and regional vegetation that can be compounded by other envinuminental stresses to plant grnwtit. Since uptake and physiological effects of these gases on tree leaves are largely i. .ediated by stomata, surrogate methods for estimating pollutant conductances into leaves and forest canopies may lead to risk assessments for major vegetation types that can then be used in regional planning. Management options to ameliorate or mitigate air pollutant damage to forests and losses in productivity are likely to be more difficult to widely implement than on-the-stack emissions abatement. Informed management and policy decisions regarding Central and Eastern European forests are dependent on the development of quantitative tools and models for risk assessment of the effects of atmospheric pollutants on ecosystem health and productivity.
\end{abstract}

\section{Introduction}

In the latter half of the 20th century, Central and Eastern European nations have experienced an unprecedented array of environmental problems affecting the ecological integrity of forests of the region. Among these problems, the issue of declining forest health has attracted considerable scientific and public interest since forests in the region have substantial economic, ecological and social value. In the 1980 's, reports of possible forest damage in Central and Eastem Europe and the implication of air pollution as a causative agent of this damage (Hinrichsen, 1986; Mazurski, 1986) heightened awareness of the effects of air

'In: Science and Technology to Save and Better Utilize Central and Eastern Europe's

Forests, R.M. Gutkowski, ed. NATO ASI Series E, Kluwer Academic Publishers, Dordrecht. 
pollution on forest productivity and sustainability. No specific air pollutant has been implicated as a causative agent of forest damage in the region, in part because the observed damage symptoms (such as leaf chlorosis and necrosis or crown dieback) are general for a wide variety of stress agents such as nutrient deficiencies, pathogens, severe drought and temperature anomalies, etc. (Schulze et al., 1989). It is now recognized that air pollution stress most likely affects forest trees in interaction with other contributing factors such as reduced levels of plant resources for growth (e.g., low nitrogen or water availability) or unfavorable biotic conditions (e.g., presence of herbivores or pathogens). Hence air pollutants can be viewed as additional stress agents that can limit tree growth and productivity in concert with other stresses (Winner, 1994). The intrinsic variability in environmental conditions in space and time, coupled with the variable distribution of pollution levels, produces a mosaic of possible impact levels of air pollution on the landscape that can be difficult to assess. The problem becomes more accentuated when multiple pollutants are considered along with other anthropogenic pressures such as improper land management practices.

A number of detailed reviews of environmental problems associated with forest damage by air pollution have appeared recently (Kandler \& Innes, 1995; Taylor et al., 1994). Instead, we will here focus on topics of special interest for forest management decisions in Central and Eastern Europe with a perspective on possible strategies for mitigating effects of air pollutants on forests.

\section{Nature of the problem}

Energy production technologies represent the largest sources of pollutant emissions in Central and Eastern Europe. Fossil fuel use and combustion technologies, particularly in the developing economies of Central and Eastern Europe, result in widespread emissions of sulfur dioxide $\left(\mathrm{SO}_{2}\right)$, nitrogen oxides $\left(\mathrm{NO}_{x}\right)$ and carbon dioxide $\left(\mathrm{CO}_{2}\right)$, carbon monoxide and volatile organic carbon compounds. For instance, in Poland $77 \%$ of the primary energy needs are met by coal-burning, which accounted for $64 \%$ of the estimated $\mathrm{SO}_{2}$ emissions from that nation (approximately 3 million tons of $\mathrm{SO}_{\dot{2}}$ Figure $1 \mathrm{~A}$ ) and over $80 \%$ of $\mathrm{CO}_{2}$ emissions (457 million tons) in 1991 (Anonymous, 1992). Much of the coal used for electricity generation in Poland and other Central and Eastern European nations is high-sulfur, "brown" (lignite) coal. In the so-called "Black Triangle" region from southern Poland to the tri-nation border area with Germany and the Czech Republic, lignite coal extraction at a rate of 200 tons year ${ }^{-1}$ over scores of years, and the operation of 17 major regional power plants have resulted in high levels of $\mathrm{SO}_{2}$ pollution believed to have contributed to forest damage in these nations (Oleksyn \& Reich, 1994). Mean annual $\mathrm{SO}_{2}$ concentrations in Upper Silesia in excess of $35 \mathrm{ppb}\left(100 \mu \mathrm{g} \mathrm{SO}_{2} \mathrm{~m}^{-3}\right.$ air $)$ were documented for 15 towns in the region in 1990-91 despite a severe economic crisis accompanied by reductions in $\mathrm{SO}_{2}$ emissions from industry at that time (Anonymous, 1992). Similar annual $\mathrm{SO}_{2}$ levels were reported in the Saxony region of former East Germany in the 1980's (Slovik et al., 1996).

Of 105 European cities of more than 500,000 inhabitants reviewed by the European Environmental Agency (EEA), over half of those in Central and Eastern Europe are estimated to exceed WHO AirQuality Guidelines $(\mathrm{AQG})$ forpollutant ozone $\left(\mathrm{O}_{3}\right)$ in thesummer months and two- 
thirds of the cities exceed the AQG for $\mathrm{SO}_{2}$ and particulates in the winter (Stanners \& Bourdeau, 1995). However, the problem is far greater than local in the sense that long-range air pollutant transport results in considerable pollutant deposition across regional and national boundaries and into nural areas. Because forests display very large surface areas for pollutant deposition or uptake into leaves, they have the capacity to sustain large doses of pollutants and large impacts on tree function resulting from long-term exposure to air pollutant emissions. Considering that much of the projected future forest products need in Europe (to the year 2020) will be supplied by forests in Central and particularly Eastern Europe (Kuusela, 1994), it is critical to assess risks to forest productivity from air pollutants and develop managment strategies to maintain sustainable yields in stands in the region.

\section{Risks to Central and Eastern European Forests by Air Pollution}

Elevated levels of the trace gases $\mathrm{SO}_{2}, \mathrm{NO}_{x}, \mathrm{CO}_{2}$, and $\mathrm{O}_{3}$ resulting from industrial emissions have well-documented physiological effects on trees (Keller, 1984; Ceulemans \& Mousseau, 1994; Matyssek et al., 1995). With the exception of $\mathrm{CO}_{3}$ these trace gases are toxic to plants and have been shown to cause reductions in tree growth which for coniferous trees can range between approximately 5 and $25 \%$ at realistic exposure levels, e.g. chronic levels that forests experience in industrialized areas (Matyssek et al., 1995). These gases enter leaves almost exclusively through the stomata and impact the internal physiology of the tree through effects on mesophyll tissue. The resultant reductions in photosynthetic processes in tree leaves are the primary mechanism of direct effects of these pollutants on tree growth and productivity. Indirect effects of these pollutants arise from the chemical changes that emitted pollutants undergo in the atmosphere resulting in $\mathrm{O}_{3}$ production and wet and dry deposition of sulfur and nitrogen compounds with subsequent cascade effects on various components of the forest ecosystem (Schulze et al., 1989; Taylor et al., 1994).

Surveys of forest damage attributable to environmental change via industrialization have been conducted in most European nations under the auspices of the EEA and the United Nations Economic Commission for Europe (UNECE). In Germany, damage level to Picea abjes canopies during 1988-1991 was strongly correlated with annual $\mathrm{SO}_{2}$ dose (Slovik et al, 1996). Poland'ssurvey in cooperation with the Commission of European Communities in 1989 showed $32 \%$ of trees were considered "damaged" in terms of putative loss of foliage from trees (Figure 1B), and its own national forest health survey indicated at least moderate acute damage symptoms on forests covering 270,000 ha in that year. In southem Poland alone, 46,000 ha of moderate to severe forest damage to Picea abies stands was noted in the 1980's in the Sudety Mountains resulting in large volumes of standing dead timber (Mazurski, 1986; Oleksyn \& Reich, 1994). Poor management has contributed to this forest decline, since forests in much of the region were harvested in the 19 th century and replaced with Picea abies in even-aged stands. While air pollution was certainly not the unique cause of this phenomenon, there is much evidence suggesting that chronic pollutant loads in the region were a major contributing factor in this forest decline. 


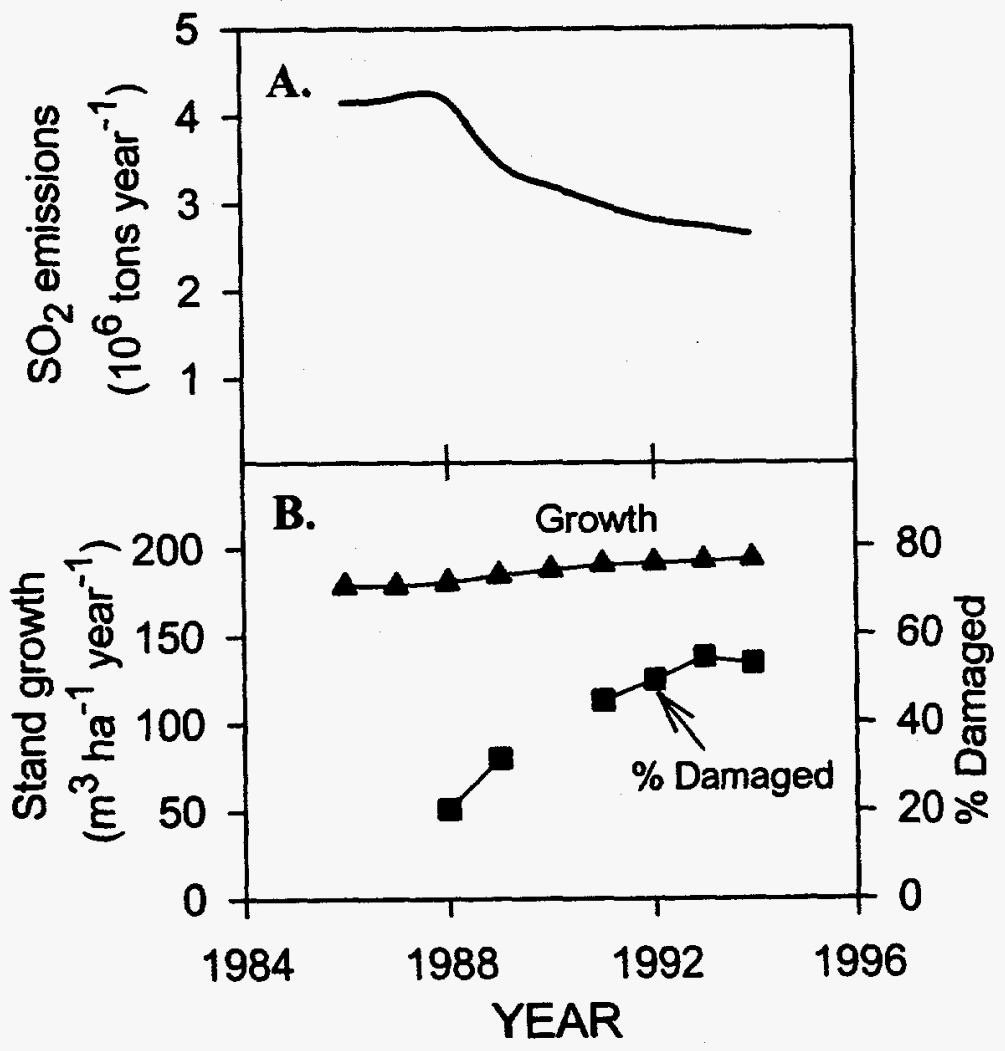

Figure 1A. Time trend in annual emissions of $\mathrm{SO}_{2}$ from Poland calculated from industrial parameters and from sulfur content of combustion fues (Anonymous, 1995; Anonymous, 1992; and previous statistical yearbooks for Poland). Note the decline in emissions beginning in the late 1980 's as a result of economic recession. Figure $I B$. Time trend of stand volume growth (all species) in state-owned forests in Poland, along with the trend of the proportion of trees surveyed that exhibited putative damage, defined as foliage loss $>10 \%$ from visual assessment. Data from a network of over 2000 plots throughout the country from the Institute of Environmental Protection, Forest Research Institute, and the Ministry of

Environmental Protection, Natural Resources and Forestry, Warsaw, Poland.

In the 1992 European survey, $24 \%$ of trees on approximately 184 million ha in Europe were considered "damaged" (e.g., loss of foliage assessed at more than $25 \%$ of the crown; 
Commission of European Communities, 1993). The damage levels were significantly higher than average for many nations in Central and Eastern Europe. While large-scale multinational surveys involving measuring very large numbers of trees will reduce error significantly, there can be bias in site selection and in the subjective evaluation of foliage and crown conditions in field surveys (Wilmot et al., 1995). Also, it is difficult to translate results from such surveys into more relevant terms such as losses in volume growth or biomass production. As illustrated by the data in Figure 1 for Poland, a simplistic approach to estimating pollution effects on forest production is not possible, since at a national level the data exhibit a dramatic decline in $\mathrm{SO}_{2}$ emissions in the late 1980's despite an increase in the proportion of stands exhibiting damage symptoms. While the volume growth data and the forest damage surveys in Figure 1B were not conducted at the same time or on the same stands, it is clear that a closely coordinated, quantitative and less subjective approach is needed to be able to evaluate the risk of air pollution to forests in Poland and among Central and Eastern European nations.

A more quantitative approach to assess the risk of impacts of air pollutants to forests in Central and Eastern Europe may be possible using the 'water-vapor surrogate' method whereby atmospheric pollutant uptake is calculated from measurements of ambient airpolhtant concentrations, canopy conductance to water vapor, and substitution of the water flux out of a forest canopy by the pollutant flux into the canopy using biophysical principles (Matyssek et al., 1995). Since data on ambient air pollutants and climate and forest water balance exist for many areas, there is a potential for the development of analytical tools for predicting vegetation risk to exposure to air pollutants that can then be used in management and regional planning efforts. While the dose-response characteristics of many tree species have not been evaluated, the water vapor surnogate approach may be applicable to species with high dominance in forested landscapes once sufficient data become available. Moreover this approach will be most valuable when linked with forest growth models and stand productivity estimates, and has the advantage that extensive field measurements at many sites are possible. A variant of the water vapor surrogate approach was applied by Sloviket al. (1996) to Norway spruce in Germany, demonstrating a parallel decrease in ambient $\mathrm{SO}_{2}$ dose and crown damage related to mandatory regulation of $\mathrm{SO}_{2}$ emissions from industry in the late 1980's. Hence this approach shows promise for widespread application, and it is currently under evaluation by the European Monitoring and Evaluation Program (EMEP/ECE) for spatial characterization of regional $\mathrm{O}_{3}$ risk to vegetation.

Despite much indirect evidence of the impact of air pollutants on forest condition and physiological function, recent assessments suggest that roundwood production in Europe has increased over the past decade (Kuusela, 1994). This appears to be largely a result of afforestation and to a lesser extent more efficient harvesting technology, the maturing age of European forests, and possible growth enhancements by atmospheric nitrogen deposition and increasing atmospheric $\mathrm{CO}_{2}$ concentration. While the latter two conditions may to some degree mitigate the effects of other environmental pollutants by stimulating tree growth, these enhancements may be transient until the onset of critical limitations by other resources such as water ormineral nutrients (Hinrichsen, 1986; Schulze, 1989; Ceulemans \& Mousseau, 1994). Although there may be some technical difficulties in assessing the economic impacts of air pollution on forest production (since 'damaged' and unaffected stands are rarely located in otherwise completely comparable environments), recognition by governments and industry of 
quantifiable impacts on forests is an important precursor to policy or management strategies for maintaining forest health and productivity.

\section{Options for Mitigating Air Pollution Losses}

\subsection{FOREST FERTILIZATION}

Fertilization of forest stands has a long history as a management alternative. While this strategy has been applied most successfully in intensively-managed, short-rotation forests used in industrial pulpwood production, it has also been widely suggested as an appropriate ameliorative strategy for forests undergoing growth declines (Hüttl, 1989). More specifically, forest liming or base cation fertilization have been proposed to ameliorate symptoms of nutrient deficiency in forests where acidic deposition and elevated ozone may have promoted this condition through elevated base cation leaching from foliar surfaces or from surface soil horizons (Zottl \&Huttl, 1986; Evers \& Hittl, 1990). This approach would also be useful in areas where soil fertility has been degraded by logging and soil erosion, or by toxic metal contaminants from mining and smelters. In Germany, a national program in the 1980's undertook the large-scale liming and fertilization of over 1 million hectares of damaged forests at a rate of 2-3 tons ha ${ }^{-1}$ lime or amended lime (Huttl \& Zottl, 1993). However, longterm data from liming trials have yielded mixed results indicating that this strategy may not be a long-term solution (Huttl \& Z8ttl, 1993; Wilmot et al., 1996). Frequently, heavy applications of lime ( 1 ton ha ${ }^{-1}$ or greater) are required on acid soils to sufficiently alter soil $\mathrm{pH}$ such that nutrient availability can be elevated, or to overcome adsorption onto soil colloidal surfaces (Wilmot et al., 1996). Forest liming at such rates may have detrimental effects on the rhizosphere (Persson \& Ahlstrom, 1990), soil microbial processes and groundwater quality (Kreutzer et al., 1989; Marschner et al., 1992). In many cases, the effects of chemical fertilizers can be short-lived because much of the fertilizer is leached out of the system, or causes an initial growth stimulation that may dilute foliar nutrients and thus exacerbate the initial condition once soil nutrients return to their initial level.

Primary operational factors limiting the utilization of fertilization as a management alternative include the prohibitive cost of purchasing and applying fertilizers in forests, the potential need for application on vast land areas, the lack of diagnostic guidelines for the type of fertilizer mixture needed, the limited access to some forest areas for fertilizer application, and lack of knowledge of the efficacy of single or multiple fertilizer applications to a variety of sites. Because of these considerations, the use of fertilizers in European forestry is rare, except in limited areas of the U.K. and Germany. Economic considerations alone have limited the use of fertilization in many forest systems, and are likely to be paramount in dictating whether this approach will be widely applied in Central and Eastern European forests.

\subsection{REFORESTATION}

Extensive land conversion from forests to agriculture has occurred in Central and 
Eastern Europe as a result of development and expansion of agriculture, particularly in the last 100 years. The increasing fragmentation and over-exploitation of forests, coupled with forest damage and loss of productivity by anthropogenic pollutants has severely degraded the biotic resources of the region. Reforestation or natural afforestation of marginal agricultural lands can help restore the ecological integrity of former forest sites. Because of the nature of anthropogenic disturbances in many locations, some candidate sites for reforestation may need to be planted with species or genotypes that are tolerant of environmental stresses such as drought, acid soils, soil contamination by toxic metals, and elevated atmospheric pollutant loads in order to assure successful plantings.

Reforestation efforts most commonly involve coniferous trees in Europe. Some provenances and genotypes of Scots pine (Pinus sylvestris) have been found to be especially susceptable to air pollution damage and hence may not be appropriate for reforestation in some regions (Białobok et al., 1984; Oleksyn, 1988). From a number of comparative studies it appears that more productive clones/provenances have greater susceptibility to air pollution, probably due to greater physiological exposure dose via pollutant uptake through stomata. Hence in Scots pine, more northern provenances appear to be less susceptible to chronic pollution in central Poland than are local provenances (Oleksyn, 1988). In some areas subject to acute pollution exposure, Austrian pine (Pinus nigra) has been adopted for reforestation efforts because of its low inherent physiological uptake for air pollutants and hence reduced incidence of air pollution damage symptoms (Oleksyn et al., 1987). While caution must be used in selecting species and provenances for reforestation efforts, it appears that native species but not necessarily native genotypes are to be encouraged for reforestation on marginal sites or in areas of chronic air pollution. Ultimately, the management goals for reforestation along with site conditions (including atmospheric and soil pollutant exposure) must dictate what kind of plant material is used.

According to many authors, genetic variation in tree sensitivity to pollution is not a sufficient argument for resistance breeding. There are several reasons for this, such as the forseeable exhaustion of the known resources of lignite and hard coal (the main source of pollution in Central and Eastem Europe), the lack of stability of the chemical composition of emissions through time, the existance of ecological variability that affects tree resistance to pollutants (e.g., variability in soils). Perhaps most important of all are the ethical considerations of plant breeding for air pollution resistance. Resistance breeding cannot be justified as an alternative to emission control, but it is a component of a comprehensive pollution control strategy that can be recommended with caution under very special circumstances (Gerhold, 1977).

\subsection{ATMOSPHERIC ENHANCEMENT OF FORESTS}

While it is generally not considered to be an 'option' for the future, the possibility of atmospheric enhancements of the condition and growth of forests is of major interest to forest managers and wood technologists. There is little question that a sharp rise in global atmospheric $\mathrm{CO}_{2}$ concentration as a result of fossil fuel combustion and deforestation has been documented in this century and is expected to continue into the next one (Houghton \& Meira-Filho, 1995). Seven European nations including Poland, Russia and the Ukraineare among 
the 15 countries that emit the largest quantity of $\mathrm{CO}_{2}$ annually as of 1995 . The increase in atmospheric $\mathrm{CO}_{2}$ concentration has important implications for tree function although the longterm sustainability of the ' $\mathrm{CO}_{2}$ fertilization effect', the $\mathrm{CO}_{2}$-induced stimulation of photosynthesis in trees and other plants, is still the subject of much investigation. There is evidence of an increase in subalpine tree growth in the Austrian Alps beyond the simple constraints of climatic variation in this century (Nicolussi et al., 1995), suggesting that some sensitive forest types already exhibit this growth stimulation. Considerable scientific debate has focussed on whether $\mathrm{CO}_{2}$-induced growth stimulation of trees in the field can be sustained over a tree's lifespan without increased biological requirements for other resources such as nutrients (Ceulemans \& Mousseau, 1994). Also, interactions between $\mathrm{CO}_{2}$ and other components of the atmospheric environment of forests in Central and Eastem Europe have not yet been evaluated. It is often suggested that rising atmospheric $\mathrm{CO}_{2}$ concentration into the future could offset stress-induced losses in tree growth and net production, or losses due to air pollutants such as $\mathrm{SO}_{2}$ and $\mathrm{O}_{3}$. Evidence from some experimental studies suggests the inhibitory effects of $\mathrm{O}_{3}$ on photosynthetic capacity in trees may be exacerbated rather than ameliorated by elevated $\mathrm{CO}_{2}$ (Kull et al., 1996). It is unlikely that gains in growth resulting from increasing atmospheric $\mathrm{CO}_{2}$ in future decades will ameliorate effects of other atmospheric pollutants on plant function. Since increasing atmospheric $\mathrm{CO}_{2}$ is a global prospect for the forseeable future, interactive effects on forests between elevated $\mathrm{CO}_{2}$ and other air pollutants such as elevated $\mathrm{O}_{3}$ or $\mathrm{SO}_{2}$ concentrations will probably still be perceptible in 50 years as growth differences between stands under unpolluted versus polluted conditions in otherwise similar environments. Moreover, effects of elevated $\mathrm{CO}_{2}$ on other components of forest ecosystems such as carbon and nutrient cycling between trees and the soil may further alter ecological processes in forests that are subjected to local and regional air pollution.

\section{Conclusions and Policy Options}

Many of the current environmental difficulties facing Central and Eastern Europe in the 1990's can be traced to an emphasis on industrial production in the previous three decades in the region and to poor governmental organization and lack of enforcement of environmental protection laws. With the large-scale governmental changes associated with changes in the ruling structure of many Central and Eastern European nations, there is a strong need for legislative mandates for clean air and environmental protection to reverse previous mismanagement. While there are still a number of pressing research needs regarding air pollutant effects on vegetation, enforceable controls should be implemented in the near furure to 'err on the side of environmental protection', given the anti-environment tendency of the past regimes in Eastern Europe in this century. Financial incentives for environmental protection must be created to assure modernization of environmental controls and implement ecologically-sound development. These options are far more tractable to implement than are management options to mitigate chronic and acute air pollution impacts on forest lands. Once it is clearly understood that environmental pollution can lead to losses in forest (and agricultural) productivity and threatens the economic vitality of forest management, then it will become possible to develop regional plans for maintaining the ecological as well as economic vigor of forests in Central and Eastern Europe. 


\section{Pertinent Observations from the ARW}

Based on the presentations at the ARW in this volume, it is clear that air pollution is considered to be the major environmental factor affecting forests in Central and Eastem Europe. There appears to be strong consensus on this issue among scientistsfrom Central and Eastern Europe who are familiar with forestry in the region, almost surprisingly so compared to the North American perspective on the problem.. It was said at the meeting that "We can live from the compound interest on our forests (e.g., growth), not the capital". The fact that air pollution is diminishing this 'interest', and its implications for the future growth of forests throughout Central and Eastem Europe is a perspective that should not be lost on any inhabitant of the region with interests in forestry and forests.

Finally, for one who has been concerned with research to understand the basic physiological and ecological processes of trees that may be altered by exposure to atmospheric pollutants and increasing atmospheric $\mathrm{CO}_{2}$ concentration, the concept of carbon sequestration by wood utilization offers possibilities to stabilize a component of global atmospheric change. This option appears to have not been fully considered by the UNEP's Intergovemmental Panel on Climate Change (IPCC) in their recommendations to policy makers, and merits serious consideration for implementation in nations with sufficient forest resources and high percapita emissions of so-called 'greenhouse' gases.

Many participants at the ARW had the sense that the populations of highly developed nations were becoming increasingly marginalized from forests and forestry. This is largely a phenomenon of the increasing urbanization and suburbanization of Europe's population, which results in forestry activities being increasingly carried out on private land and away from the view of the general population. Media attention in Europe has become attracted only to examples of mismanagement of forests, as is also true in North America. The emerging view from the ARW of the importance of education the general public regarding the possible benefits of forestry and forest managment to current and the future populations in the region cannot be overemphasized. A common theme at the ARW was one of optimism reganding forest resources in the face of pastmismanagement and environmentai problems in Central and Eastem Europe. In the present atmosphere of emerging nations and international cooperation in Europe, we forsee even greater promise for the region's forests as long as those who make management decisions do not overlook environmental priorities.

\section{References}

Anonymous. (1992) Rocznik Statystyczny 1992. Gtowny Urzad Statystyczny, Rok LII, Warszawa, Poland. [Statistical Yearbook 1992. State Main Statistical Office, Volume 52, Warsaw, Poland].

Anonymous. (1995) Rocznik Statystyczny 1995. Glowny Urzad Statystyczny, RokLV, Warszawa, Poland. [Statistical Yearbook 1995. State Main Statistical Office, Volume 55, Warsaw, Poland]. 
Białobok, S., Oleksyn, J. \& Rachwal, L. (1984) Selection of trees and shrubs for forest restructuring in industrial regions. In Grodziniski, W.; Weiner, J. \& Maycock, P.F. (eds.), Forest Ecosystems in Industrial Regions, Springer, Berlin, pp. 239-244.

Commission of European Communities UNECE. (1993) Forest Condition in Europe. Report of the Intemational Cooperative Program on Assessment and Monitoring of Air Pollution Effects on Forests. Results of the 1992 Survey. Commission of European Communities, Direction Générale VI, Brussels, Belgium.

Ceulemans, R. \& Mousseau, M. (1994) Effects of elevated $\mathrm{CO}_{2}$ on woody plants. New Phytologist $127,425-446$.

Gerhold, H.D. (1977) Effects of air pollution on Pinus strobus L. and genetic resistance. A literature review.U.S. Environmental Protection Agency, EPA 600/3-77-002, Corvallis, Oregon, $44 \mathrm{pp}$.

Evers, F.H., \& Huttl, R.F. (1990) A new fertilization strategy in declining forests. Water, Air, and Soil Pollution 54, 495-508.

Hinrichsen, D. (1986) Multiple pollutants and forest decline. Ambio 15, 258-265.

Houghton, J.T., \& Meira-Filho, L.G., editors (1995) The IPCC Report on Radiative Forcing of Climate Change. Intergovernmental Panel on Climate Change (IPCC), Cambridge University Press, Cambridge.

Hulttl, R.F.(1989) Liming and fertilization as mitigation tools in declining forest ecosystems. Water, Air, and Soil Pollution 44, 93-118.

Huttl, R.F., \& Zottl, H.W. (1993) Liming as a mitigation tool in Germany's declining forestsreviewing results from former and recent trials. Water, Air, and Soil Pollution 61, 325-338.

Kandler, O. \& Innes, J.L. (1995) Air pollution and forest decline in Central Europe. Environmental Pollution 90, 171-180.

Keller, T. (1984) Direct effects of sulfur dioxide on trees. Philosophical Transactions of the Royal Society of London Series B 305, 317-326.

Kreutzer, K., Reiter, H., Schierl, R., \& Göttlein, A. (1989) Effects of acid irrigation and liming in a Norway spruce stand (Picea abies L. (Karst.)). Water, Air, and Soil Pollution $48,111-125$.

Kull, O., Sober, A., Coleman, M.D., Dickson, R.E., Isebrands, J.G., Gagnon, Z., \& Kamosky, D.F. (1996) Photosynthetic responses of aspen clones to simultaneous exposures of ozone and $\mathrm{CO}_{2}$. Canadian Journal of Forest Research 26, 639-648.

Kuusela, K. (1994) Forest Resources in Europe, Cambridge University Press, Cambridge, U.K. Marschner, H., Stahr, K., \& Renger, M. (1992) Lime effects on pine forest floor leachate chemistry and element fluxes. Journal of Environmental Quality 21, 410-419.

Mazurski, K.R. (1986) The destruction of forests in the Polish Sudetes Mountains by industrial emissions. Forest Ecology and Management 17, 303-315.

Matyssek, R., Reich, P.B., Oren, R. \& Winner, W.E. (1995) Response mechanisms of conifers to air pollutants. In Smith, W.K. \& Hinckley, T.M. (eds.), Ecophysiology of Coniferous Forests, Academic Press, San Diego, pp. 255-308.

Nicolussi, K., Bortenshlager, S., \& Kömer, C. (1995) Increase in tree-ring width in subalpine Pinus cembra from the central Alps that may be $\mathrm{CO}_{2}$-related. Trees 9, 181-189.

Oleksyn, J., Oleksynowa, K., Kozlowska, E., \& Rachwal, L. (1987) Mineral content and the sensitivity of black pine (Pinus nigra) of various provenances to industrial air pollution. Forest Ecology and Management 21, 237-247. 
Oleksyn, J. (1988) Height growth of different European Scots pine (Pinus sylvestris L.) provenances in a heavily polluted and a control environment. Environmental Pollution 55, 289-299.

Oleksyn, J., \& Reich, P.B. (1994) Pollution, habitat destruction and biodiversity in Poland. Conservation Biology 8, 943-960.

Oren, R., \& Schulze, E.-D. (1989) Nutritional disharmony and forest decline: a conceptual model. In Schulze, E.-D., Lange, O.L., \& Oren, R. (editors), Forest decline and air pollution: a study of spruce (Eicea abies) on acid soils, Springer-Verlag, Berlin Heidelberg, pp. 425-443.

Persson, H., \& Ahlstrom, K. (1990) The effects of forest liming and fertilization on fineroot growth. Water, Air, and Soil Pollution 54, 365-375.

Schulze, E.-D. (1989) Air pollution and forest decline in a spruce (Bicea abies) forest. Science 244, 776-783.

Schulze, E.-D., Lange, O.L., \& Oren, R, editors. (1989) Forest Decline and Air Pollution Ecological Studies 77. Springer-Verlag, Berlin.

Slovik, S., Siegmund, A., Fuhrer, H.-W., \& Heber, U. (1996) Stomatal uptake of $\mathrm{SO}_{2} \mathrm{NO}_{x}$ and $\mathrm{O}_{3}$ by spruce crowns (Hicea abies) and canopy damage in Central Europe. New Phrologist 132, 661-676.

Stanners, D. \& Bourdeau, P., editors. (1995) Europe's Environment: The Dobtis Assessment. European Environment Agency, Copenhagen.

Taylor, G.E., Johnson, D.W., \& Andersen, C.P. (1994) Air pollution and forest ecosystems: A regional to global perspective. Ecological Applications 4, 662-689.

Wilmot, T.R., Ellsworth, D.S., \& Tyree, M.T. (1995) Relationships among crown condition, growth, and stand nutrition in seven northern Vermont sugarbushes. Canadian Journal of Forest Research 25, 386-397.

Wilmot, T.R., Ellsworth, D.S., \& Tyree, M.T. (1996) Base cation fertilization and liming affects nutrition and growth of Vermont sugar maple stands. Forest Ecology and Management, in press.

Winner, W.E. (1994) Mechanistic analysis of plant responses to air pollution. Ecological Applications 4, 651-661.

Zottl, H.W. \& Huttl, RF. (1986) Nutrient supply and forest decline in southwest Germany. Water, Air, and Soil Pollution 31, 449-462. 